\title{
Zánik starého světa očima Václava Červinky
}

\section{The end of the old world in the view of Václav Červinka}

Pavel Máša / pavelmasa@seznam.cz

Historický ústav, Filozofická fakulta, Masarykova univerzita, Brno, CZ

\begin{abstract}
This study deals with the view of Václav Červinka, son-in-low of František Ladislav Rieger, administrator of Rieger's estate Maleč and a man of many intellectual interests, on radical changes of the Central Europe at the turn of the 20th century, especially destruction of traditional political, economic, social and cultural structures, outbreak of the First World War, collapse of the Austria-Hungary and estabilishment of the independent Czechoslovakia. It is shown, how Červinka, as a man who was closely tied to the traditional conservative policy and politicians of the end of the 19th century, evaluated all these changes and what was his reaction, e. g. in his literary work.
\end{abstract}

\section{Keywords}

Czechoslovakia; František Ladislav Rieger; Habsburg Monarchy; First World War; socialism; Tomáš Garrigue Masaryk; Václav Červinka 


\section{1 Úvod}

Rok 1918 je jedním z mezníků v dějinách střední Evropy. Konec první světové války s sebou přinesl rozpad Habsburské monarchie, geografického, kulturního a mentálního rámcem, v němž se obyvatelé této části starého kontinentu po staletí pohybovali, ale také vznik několika nástupnických států. Interpretace této proměny středoevropského prostoru se u jednotlivých národních společenstev lišila. Zatímco pro Čechy, Slováky a Poláky byl pád Rakouska-Uherska počátkem nové, lepší existence v samostatných státech, z pohledu Mad’arů a Rakušanů šlo o „katastrofu“ a konec významné periody jejich dějin. Pro Mad’ary byla ztráta značné části území někdejšího Uherska „národní tragédii““1 a Rakušané, kterým nebylo dovoleno připojit se k Německu, zůstali v zemi, která byla podle slov Stefana Zweiga „nucena $k$ samostatnosti, kterou sama rozhořčeně odmítala“.2

Tyto rozdílné narativy posléze pronikly do jednotlivých národních historiografií3 a promítly se také do vztahu národů k vlastní minulosti. Na straně Rakušanů a Mad’arů vedla nespokojenost s poválečnými poměry k nostalgickému (nikoli však nekritickému) vzpomínání na předválečnou epochu, což dokumentuje i krásná literatura. ${ }^{4}$ Češi, kterým válka přinesla samostatnost a podle převažujícího názoru vymanění se z pout rakouského „násilnictvi“ ${ }^{5}$ neměli potřebu uchylovat se před současností do idealizované minulosti, a už vůbec ne do dob pověstného „žaláře národů“. Přesto bychom i v české společnosti nalezli osoby, které se cítily být doma spíše v zaniklém předválečném světě než v realitě nového státu. ${ }^{6}$ Patřil k nim i Václav Červinka, spisovatel, zet̉ Františka Ladislava Riegra a ředitel jeho velkostatku v Malči.

Ve svém příspěvku přiblížím, co pro Červinku bylo oním zmizelým světem a proč jej preferoval na úkor poválečné doby. Zajímavé bude sledovat, jaké byly strategie, s nimiž Červinka zániku „svého starého světa“ čelil, ať už v osobní, nebo veřejné sféře. Mimoto se pokusím zodpovědět otázku, zda byly Červinkovy názory a argumenty ojedinělé, nebo pro ně v kontextu české meziválečné společnosti nalezneme nějaké paralely. Využiji při tom obsahovou analýzu Červinkovy dochované rodinné korespondence ${ }^{7}$ a jeho literár-

1 Pók, Attila: Ungarische Interpretationen der Gründung der Tschechoslowakei. In: 1918. Model komplexního transformačního procesu? Edd. L. Kostrbová - J. Malínská a kol. Praha 2010, s. 40-41.

2 Zweig, Stefan: Svět včerejška. Praha 1994, s. 244.

3 Viz Kováč, Dušan: 1918. Začiatok, alebo koniec? Dva transformačné modely v strednej Európe. In: 1918. Model komplexního transformačního procesu? Edd. L. Kostrbová - J. Malínská a kol. Praha 2010, s. 11.

4 Srov. Magris, Claudio: Habsburský mýtus v moderní rakouské literatuře. Brno - Praha 2001. - Nejznámějším představitelem mad’arské literatury, u něhož nalezneme podobné motivy, je Sándor Márai.

5 Z projevu Karla Kramáře 14. listopadu 1918 v Národním shromáždění, viz Kramář, Karel: Řeči a projevy předsedy prvé vlády československé. Praha 1936, s. 15.

6 Jednalo se např. o některé katolické spisovatele. Je ovšem charakteristické, že ani mezi katolíky nehrál tento proud zásadnější roli a Jaroslav Durych, jeden z nejvýznamnějších katolických autorů té doby, který měl přitom k podobě poválečného Československa četné výhrady, jakékoli sympatie pro Habsburky u katolíků velmi ostře kritizoval, viz Putna, Martin C.: Česká katolická literatura 1918-1945. Praha 2010, s. 377.

7 Jedná se o dopisy, které Červinka posílal Albínu Bráfovi a Bohuši Riegrovi a své švagrové Libuši Bráfové. Dopisy jsou uloženy v Archivu Národního muzea, kde je i zlomek Červinkovy přijaté korespondence. V příspěvku jsem až na výjimky nemohl využít písemnosti z Červinkova fondu v Literárním archivu Památ- 
ního díla. Díky velkému rozsahu pramenné základny, která téměř rovnoměrně pokrývá období prvních deseti let existence Československa, ale rovněž mu výrazně předchází, bude možné sledovat genezi a konzistentnost Červinkových myšlenek a stanovit témata, ke kterým se opakovaně vracel a považoval je tedy za důležitá. Zajímavá zjištění může poskytnout komparace osobní korespondence s publikovanými texty, která ukáže, nakolik se lišily Červinkovy veřejně artikulované postoje od těch, které zastával v soukromí. Díky dochovaným listům se navíc lze dozvědět o okolnostech a příčinách vzniku některých Červinkových spisů, což umožňuje lépe pochopit jejich obsah a záměry, s nimiž byly psány.

\section{Uvedení do života a povahy Václava Červinky}

Václav Červinka nepatří mezi všeobecně známé postavy českých dějin, a proto je nutné alespoň stručně nastínit jeho životní osudy. ${ }^{8}$ Narodil se v roce 1844 do české vlastenecké rodiny, studoval na akademickém gymnáziu v Praze, kde se zapojil do společenského života, například se účastnil založení Sokola. Studium ale nedokončil a místo toho absolvoval hospodářské učiliště, protože měl dle přání svého otce převzít správu rodinného velkostatku v Ostředku. K tomu kvůli finančním obtížím statku nakonec nedošlo a Červinka musel pracovat jako hospodářský správce na cizích velkostatcích. V roce 1872 se stal ředitelem na velkostatku v Malči, který patřil F. L. Riegrovi. Vazbu obou mužů upevnil Červinkův sňatek s Riegrovou dcerou Marií, kterému krátce před smrtí požehnal i Mariin dědeček František Palacký. Manželství však nebylo štastné a partneři žili až do Mariiny smrti roku 1895 odloučeně. Červinka během svého působení úspěšně zmodernizoval správu malečského statku, který se ale i nadále potýkal s finančními problémy. Po Riegrově smrti v roce 1903 rodina velkostatek pronajala a Červinka se následujícího roku z Malče odstěhoval, čímž skončila jeho profesní dráha. Zbytek života strávil ve Štěpánově, Rochňovci a od roku 1919 v Chotěboři, kde na podzim 1929 zemřel.

Červinka měl mnoho zájmů. Miloval lov, amatérsky se věnoval hudbě, filozofii, přírodním a hospodářským vědám a podrobně sledoval rovněž politiku. Řadil se mezi staročechy a jeho politické přesvědčení a hodnotový systém výrazně ovlivnily osobní styky s Palackým, a především s Riegrem. S „vůdcem národa“ trávil mnoho času při jeho pobytech v Malči a lze o něm skutečně hovořit jako o Riegrově důvěrníkovi, ${ }^{9}$ což je patrné

níku národního písemnictví, který není zpracován a byl mi zpř́ístupněn teprve nedávno. Pro téma práce to však nepředstavuje závažnější komplikaci, protože se jedná téměř výhradně o dopisy, které byly Červinkovi adresovány, a jeho vlastní názory se v nich tedy odrážejí pouze nepř́ímo.

8 Blí̌e viz Neradová, Zlatuše: Václav Červinka. Ze života rodiny českého vzdělance ve druhé polovině 19. století. Nepublikovaná diplomová práce. PF JU. České Budějovice 1994.; Vojáček, Milan: Na velkostatku vůdce národa. Edice Pamětní knihy Malče. Praha 2014. - Vojáček je mimoto autorem řady dílčích studií o Červinkově literárním díle a jeho hospodaření na Malči.

9 Viz Vojáček, Milan: Odkaz budoucím generacím. Literární obraz vlastní rodiny vytvořený Marií Červinkovou-Riegrovou a jejím chotěm Václavem Červinkou. In: Žena umělkyně na přelomu 19. a 20. století. Sborník př́íspěvků z mezinárodní konference ve Stř̌edočeském muzeu v Roztokách u Prahy ve dnech 11. a 12. ř́ijna 2005. Roztoky u Prahy 2005, s. 213. 
také z dopisů, které mu Rieger posílal z Prahy a Vídně. Červinka si této pracovní i osobní vazby na „vůdce národa“ velmi vážil a vždy považoval za svoji povinnost chránit Riegra a jeho dobré jméno. Výmluvná je v tomto ohledu známá př́ihoda ze začátku 90. let, kdy Červinka neváhal vyzvat na souboj mladočecha Jana Vašatého, který na českém zemském sněmu při projednávání punktací označil Riegra za „bídného zrádce“.

Velkou Červinkovou vášní byla literatura. Napsal několik prozaických děl pod pseudonymem Q. F. Renatus, zajímavěji však působí jeho vzpomínkově laděné texty, v nichž vystupuje mnoho významných postav českého kulturního a politického života 2. poloviny 19. století, které autor díky svému rodinnému zázemí, studentskému životu v Praze a vazbám na Riegrovu rodinu osobně znal. V těchto pracích se silně odráží svérázný naturel a styl autora. Červinka měl složitou povahu, byl náladový samotář, nerad cestoval, ale přesto za svého života navštívil řadu evropských zemí, například Itálii, Francii a podíval se i do Ruska. Můžeme jej tedy považovat za přemýšlivého člověka, který měl především díky samostudiu poměrně široký rozhled, na druhou stranu nebyl nijak originální a hluboký myslitel ani spisovatel. To vše jsou okolnosti, které je třeba brát v potaz při posuzování jeho názorů na proměnu života české společnosti po roce 1918.

\section{Starý a nový svět}

Hovoříme-li o Červinkově nostalgii po předválečných časech, rozhodně tím není míněn stesk po vládě Habsburků. Pokud můžeme důvěřovat jeho pozdějšímu vyprávění, už jako student se k Rakousku stavěl velmi negativně a byl přesvědčen, že jednoho dne musí monarchie na svůj nevděk vůči Slovanům uvnitř i vně svých hranic doplatit, ačkoli nevěřil, že se té chvíle sám dožije. ${ }^{10}$ 28. říjen 1918 proto přivítal podle vlastního svědectví s nadšením, ${ }^{11}$ které ale nevydrželo dlouho. Už za necelý měsíc nalezneme v jeho korespondenci první známky nespokojenosti s novými poměry: „Spíše cítím nechut', ba časem přimo odpor k celému veřejnému životu. A to je i prí tom, když jsme vojensky vyhráli. Jak by to bylo cítit, kdybychom byli prri tom vojnu prohráli a nyni nás pronásledovali. No - to už tak u starých lidí bývá, a můžete si myslit třeba, že jsou to jen známky a projevy - stáři. Ale mohu s dobrým svědomím ř́ci, že donedávna jsem nebýval ani nevrlý, ani nespokojený... No - nějak bude. "12

Červinkova slova je nutné vnímat s určitou rezervou. Nespokojenost s veřejným děním a českým politickým životem zvlášt vyjadřoval v soukromých listech běžně už před válkou. S nelibostí sledoval vývoj po letech 1890-1891, kdy padl Rieger i celá staročeská strana a do čela národa se dle jeho soudu dostali Riegrovi političtí odpůrci, kteří dílo

10 Červinka, Václav: Od dětství do kmetství. Některé vzpomínky, zážitky a úvahy. Praha 1923, s. 36-37. - Doklady, že Červinka viděl budoucnost Rakouska černě, nalezneme také v jeho korespondenci na přelomu století, viz Archiv Národního muzea v Praze (dále jen ANM), fond Libuše Bráfová (dále jen LB), kart. č. 5, Červinka Bráfové, 22. 3. 1901; 15. 11. 1909.

11 Červinka, V.: Od dětstvi do kmetství, s. 61. - Červinkovu reakci na 28. ř́jjen se mi v jeho korespondenci bohužel dohledat nepodařilo.

12 ANM, fond LB, kart. č. 5, Červinka Bráfové, 22. 11. 1918. 
a odkaz „vůdce národa“ systematicky ničili. ${ }^{13}$ Je ale pravda, že po roce 1918 došlo v Červinkově kritice soudobých poměrů $\mathrm{k}$ dramatickému posunu. ${ }^{14}$ Nelibost vyjadřoval stále častěji, příkřeji a mnohdy veřejně. Odsuzoval především celkový poválečný vývoj, jímž byla relativizována dokonce i hodnota nově nabyté samostatnosti. Červinka tak například psal s notnou dávkou sarkasmu o „naši republice blahoslaveně vrtácké “15 nebo krátce před desátým výročím 28. října poznamenal, že je dobře, že se bývalý „vůdce národa“ Rieger nedočkal „naši tzv. samostatnosti, která by mu byla přinesla nejedno zklamáni“. ${ }^{16}$

Příčin, proč Červinka nebyl s životem v meziválečném Československu spokojen, bylo více. Zcela jistě hrály roli osobní poměry. V roce 1918 bylo Červinkovi sedmdesát čtyři let, jeho zdravotní problémy, s nimiž se potýkal již dříve, se postupně zhoršovaly a sám připouštěl, že je tím ovlivněna jeho nálada, odpor k př́ítomnosti a častější vzpomínání na dřívější doby. ${ }^{17}$ Postupně odcházeli jeho příbuzní, známí, přátelé a celá jeho generace, kvưli čemuž se cítil stále více osamocen. ${ }^{18}$ Neuspokojivá byla také jeho finanční situace, ${ }^{19}$ především ale postrádal hlubší smysl svého bytí. Téměř celý aktivní život spojil s velkostatkem v Malči a ačkoli se jednalo o obtížnou práci, která mu dle jeho vlastních slov přinášela spoustu starostí a poměry pro něj „hmotně ne právě nejskvělejši“", považoval tento úřad a postavení za svoji čestnou povinnost „vưči nezapomenutelnému majiteli těch statkư “.20 Už roku 1898 napsal, že pokud by Rieger statek kvůli finančním potížím prodal, viděl by tím „svưj úkol, svou práci skončenou - snad pro tento život“. ${ }^{21}$ Po Riegrově smrti a pronájmu Malče se Červinka skutečně stáhl do ústraní a nadále žil především ve svých vzpomínkách, jak se opakovaně vyjádřil ${ }^{22} \mathrm{~S}$ postupujícím věkem docházel k závěru, že jeho život nebyl úplně štastný a naplněný, a necelý rok před smrtí vyjádřil lítost nad tím, že raději nezůstal u hudby a literatury, které mu byly nejbližší. ${ }^{23}$

Nemenší vliv na příkré hodnocení nového státu mělo tehdejší veřejné dění. Červinka sdílel rozčarování části české společnosti z popřevratové „divoké doby, kdy se zdálo, že je vše povoleno “. ${ }^{24}$ Ve svých dopisech kritizoval drahotu, ketasení, hospodářskou situaci, fungování

13 Např. ANM, fond LB, kart. č. 5, Červinka Bráfové, 23. 6. 1910; 25. 11. 1912.

14 Tento rozdíl vynikne při srovnání Červinkových poválečných prací s jeho vzpomínkovými texty napsanými ještě před vznikem samostatného státu, viz Červinka, Václav: U kolébky Sokola. Vzpomínky účastníkovy. Praha 1920. (napsáno 1912); Týž: Z jarního rašeni národního života v letech 1855-1865. Osvěta 1912, s. 272278, 370-375, 437-444, 514-522, 665-672, 748-751. - Týž (pseudonym Renatus, Q. F.): Za Otakarem Červinkou. Národní politika, 11. 6. 1915, s. 2-3.

15 ANM, fond LB, kart. č. 5, Červinka Bráfové, 12. 11. 1920.

16 Tamtéž, ANM, fond LB, kart. č. 5, Červinka Bráfové, 15. 7. 1928.

17 Tamtéż, Červinka Bráfové, 14. 7. 1920.

18 Tamtéž, Červinka Bráfové, 25. 9. 1924.

19 Tamtéž, Červinka Bráfové, 19. 7. 1921; 20. 2. 1929.

20 Literární archiv Památníku národního písemnictví v Praze (dále jen LA PNP), fond Václav Vlček, dopis Červinky Vlčkovi, 26. 1. 1904.

21 ANM, fond LB, kart. č. 5, Červinka Bráfové, 20. 3. 1898.

22 Tamtéž, fond Bohuš Rieger st., kart. č. 8, dopis Červinky Riegrovi, 8. 8. 1905.

23 Tamtéž, fond LB, kart. č. 5, Červinka Bráfové, 28. 1. 1929.

24 Kárník, Zdeněk: České země v ére proni republiky (1918-1938). Díl 1. Vznik, budování a zlatá léta republiky (1918-1929). Praha 2003, s. 56. 
veřejných služeb (např. pošty) a všudypřítomné krádeže. ${ }^{25}$ Pocit, že se rozpadl stávající řád a státní moc není schopna obnovit a udržet pořádek, byl u Červinky prožíván velmi intenzivně: „Beztoho v republice dělá každý co chce, a když se nedá, tak mu to projde. ${ }^{\text {(26 } 6}$ Tento kritický pohled se nezmírnil ani po stabilizaci právních a hospodářských poměrů ve 20 . letech a Červinka jej zastával až do své smrti. ${ }^{27}$

Červinkovi se nezamlouval ani vznik společného státu Čechů a Slováků, ke kterým choval averzi a nedůvěru na základě svých dřívějších nijak blíže nespecifikovaných osobních zkušeností. ${ }^{28}$ Byl přesvědčený, že soužití Čechů se Slováky je nestabilní, pro Čechy nevýhodné a potenciálně nebezpečné pro jejich samostatnost: „Poslední groš strčime do Slovenska, až jim to všechno hezky zař́díme, tak od nás odpadnou, a nás potom neb dřív strči zas pod nĕjakou korunu a budeme hotovi: republiko, takhle prohraješ všecko! “29 Z tohoto výroku je rovněž patrná Červinkova skepse k mezinárodnímu postavení Československa, které až příliš záviselo na zájmech mocnějších evropských států. Jinak se ovšem Červinka ve svých dopisech a textech o mezinárodním dění a československé zahraniční politice téměř nevyjadřoval.

Všechny tyto motivy však hrály v Červinkových očích spíše vedlejší úlohu. Zásadním nedostatkem české poválečné společnosti byl podle něj její charakter a hodnoty, což vyniklo zvláště při srovnání současného stavu s tím, co bývalo dříve: „Pro takovou úpravu naši domoviny, jaká se začiná z toho proniho hluku slavnostního vybarvovat - mám málo smyslu, ježto mi vnitřni hlas pravi, že to neni na dobré cestě. Vykládat proč, si uspořim. Jsem zkrátka odchovanec minulého stoleti a v něm zase doby onoho našeho nadšeni národního a z něho tryskajicich názorů - snad více ideálnich - jaké vytrysklo ze zmučených srdci našich v létech šedesátých po vlaské vojně r. 1859, a to ve všem, ani ty názory nekryji se přesně s dnešními. Arci je tomu už šedesát let, ale národ dnešní by si mohl blahopřát, kdyby měl dnes ledacos z toho, co bylo tenkrát. "30

Zde se dostáváme k tomu, co vlastně bylo oním starým světem, na který Červinka s nostalgií vzpomínal. Jednalo se celkem přirozeně o dobu jeho mládí, jejíž význam měl ale také silnou nadosobní rovinu. Červinkova generace dospívala za Bachova absolutismu, zažila jeho pád a následný rozkvět českého národního života v 60. letech 19. století. Červinkovi se toto období zpětně jevilo jako mimořádná chvíle českých dějin, okamžik rozmachu nadšeného, ideálního, nezištného a obětavého vlastenectví, doba národní svornosti a spolupráce při snaze vybudovat základy českého kulturního, společenského a politického života, díky kterým bylo možné jednoho dne přivést národ ke svobodě. ${ }^{31}$

25 „Republikánský národ český činí v darebáctví (...) značné pokroky. Možná že budou okazovat člověka kterému ještě nic neukradli. Mě letos ukradli část jablek a kachny. "Viz ANM, fond LB, kart. č. 5, Červinka Bráfové, 12. 11.1920.

26 Tamtéž, Červinka Bráfové, 30. 11. 1920.

27 Tamtéž, Červinka Bráfové, 1. 6. 1929.

28 Tamtéž, Červinka Bráfové, 12. 8. 1927.

29 Tamtéž, Červinka Bráfové, 30. 11. 1919. - Paradoxně krátce po válce Červinka uvažoval, že by se přestěhoval na Slovensko, kde se podle něj dalo finančně lépe vyžít, viz tamtéž, Červinka Bráfové, 5. 2. 1919.

30 Tamtéž, Červinka Bráfové, 30. 3. 1919.

31 Svoje vnímání 60. let Červinka zachytil ve spisu Od dětství do kmetství, který měl být oslavou této doby a současně kritikou poválečných poměrů, viz Červinka, Václav: Od dětstvi do kmetství. - O motivech sepsání brožury viz ANM, fond LB, kart. č. 5, Červinka Bráfové, 17. 12. 1922. 
Jenže právě po válce se dle jeho soudu Češi k odkazu 60. let otočili zády. Měl pocit, že vidí „ׁ̌́m dál tím méně našeho národa - totiž toho, který jsem vidíval, znal, - za to však tím více všelijakých postav, stran, barev, straniček, které nebývalo vidět dříve. Posléze užasnul jsem, když setkával jsem se s novými úkazy a hesly nazíráni takového, jaké za dob mého mládi bylo v národě neprípustné, nemožné. Tu vzpominky mé počaly mluviti v mé duši: Bylo by za mého mládí bývalo možno, aby někdo z Čechů nazval myšlenku národni něčim špatným, hřísným, - tudiž v nĕjakém směru škodlivým a vlastenectví - asi tak - jedovatou nákazou?".32

Rovněž v tomto př́ípadě je nutné Červinkovu výpověd' korigovat. Není pravda, že „úkazy a hesla“, které mu v novém státě vadily, dříve nepozoroval. Mnoho jevů, které podle něj stály za úpadkem národního cítění a o kterých bude dále řeč, vnímal velmi kriticky už před válkou a uvědomoval si, že mají poměrně hluboké kořeny. Zřejmě ale doufal, že dosažení vytoužené svobody povede k opětovnému posílení vlastenectví v české společnosti. K tomu však dle jeho soudu nedošlo a situace se nadále zhoršovala. Zajímavá je strategie, s níž Červinka tomuto vývoji čelil. Na jednu stranu ještě víc omezil svoje osobní styky s vnějším světem a uzavřel se na svém „chotěbořském Špilberku“,33 odkud v dopisech psaných švagrové Libuši Bráfové kriticky komentoval aktuální dění i obecnější společenské trendy. Na druhou stranu se v průběhu 20. let odhodlal skrze svoje literární a publicistické dílo několikrát veřejně vystoupit, aby podrobil kritice nové pořádky, stejně jako obhájil a připomenul staré vlastenecké hodnoty, na které se podle jeho přesvědčení zapomínalo, ${ }^{34}$ pokud na ně nebylo dokonce přímo útočeno jako na nepotřebnou „veteš“. 35

\section{Stranictví}

Permanentním tématem Červinkových kritických úvah bylo stranictví, které považoval za velmi nebezpečné, protože „přestane-li býti národ národem, rozpadaje se na strany mocnějši nad celkový jeho zájem - prestane i jeho moc - a přestane i jeho samostatnost" ${ }^{36}$ Na počátku 60. let 19. století si cenil právě toho, že „nebylot’ tehdáž stran a různých směrů v národě“. ${ }^{37}$ Tento stav ale netrval dlouho. Už při polském povstání v roce 1863 se mezi českou politickou reprezentací plně projevily spory vedoucí až k pozdějšímu rozdělení na staročechy a mladočechy. Rok 1863 tak byl pro Červinku počátkem všech pozdějších neúspěchů české

32 Červinka, Václav: Od dětství do kmetství, s. 61-62.

33 ANM, fond LB, kart. č. 5, Červinka Bráfové, 13. 11. 1919.

34 „Vidim, že po prevratu zapominá se poněkud na naši nedávnou svizelnou minulost a že dívaji se některé vrstvy českého lidu jinak na povinnosti $k$ národu a otčině, než nazírali jsme za dob mládí my a celá naše doba. Vidím $v$ tom nebezpeči pro naši budoucnost. Proto myslím, že nebude na škodu mladším, upozorniti je na některé zážitky a dojmy z mládi svého, a porovnati je s dojmy, jež vyvíraji z vývoje přitomnosti. "Viz Červinka, Václav: Od dětství do kmetství. Některé vzpomínky, zážitky a úvahy. Praha 1923, s. 7.

35 ANM, fond LB, kart. č. 5, Červinka Bráfové, 17. 12. 1922.

36 Červinka, Václav: Otevřený list Národni radě československév př́ičině pozemkové opravy. Praha 1923.

37 Týž: Od dětstvi do kmetství, s. 33. 
politiky, ${ }^{38}$ která tř́ístila síly v „boji bratrovražedném“ místo společného postupu proti Vídni. ${ }^{39}$

Dalším mezníkem byla v tomto ohledu 90. léta. Z čela české politiky byli smeteni staročeši a na politické scéně se začaly prosazovat nové proudy, např. realisté, pokrokáři, katolická hnutí, agrárníci či sociální demokraté. Červinkovi se tento vývoj pochopitelně nelíbil, protože v něm spatřoval další oslabování národa. Nedocházelo mu, že národní jednota, jak ji on sám chápal a požadoval (podobné stanovisko ale tehdy zastávali mnozí staročeši i jejich nástupci z mladočeského tábora), byla ve skutečnosti pozůstatkem myšlení dřivějších fází národního obrození a že v rozvíjející se a stále více se diferencující české společnosti byla taková představa neudržitelná. Tento vývoj opravdu svědčil spíše než o brzkém „konci národa“ o jeho životaschopnosti. ${ }^{40}$ Červinka byl nicméně přesvědčen o opaku a politický systém první republiky, který na vlivných a společnost v mnoha oblastech prostupujících stranách stál, považoval za další krok k rozpadu národního života: „Celá politická i národni veřejnost jsou jen strany, straničky, osobni zájmy a pikle, samé spolky, společky, svazy, v̌se jedna spletená sít, v které se zadrhuji samé uzlićchy které pomalu nikdo nerozplete, a v kterých tone celý společenský (už ani neřikám národní) život..." "41

To byl také důvod, proč Červinka veřejně vyzdvihl roli Sokola v poválečné době, protože to podle něj byl jeden z mála integračních prvků české společnosti, který navíc mohl svojí činností posilovat národní vědomí: „A zaradoval jsem se, když viděl jsem v kalném příboji na vzájem se prevalujicich vln strannictvi státi neochvějně známou žulovou skálou onoho starého nesmlouvajicího, a proto věčně mladého vlastenectvi jak jsem je z mládi znal, jehož viditelným znamením jest prápor sokolský. "42 Podobně se vyjadřoval i v soukromí, kde sice připustil, že se soudobým Sokolem nesouhlasí ve všem, ale i tak je to jediný sympatický spolek, protože „nejméně politisuje a má pro národ předce jen nejzdravějši směry - a také $i$ zásluhy“. ${ }^{3}$

Ještě daleko závažnější byl podle Červinky jiný jev, který s 90 . léty a rozvojem politického stranictví souvisel. Růst vlivu stran založených na třídním či stavovském principu už nebyl pouhým štěpením sil, jednalo se o zcela odlišný pohled na svět, kdy byl dílčí zájem určité části společnosti postaven naroveň, někdy dokonce i nad zájem celého národa, o který by přitom mělo jít každému Čechovi především. Červinka se v té době osobně setkal jak s projevy rostoucího sociálního napětí, ${ }^{44}$ tak s počátky agrárního hnutí na venkově. ${ }^{45}$ Uznával, že potřeby dělníků a rolníků jsou často oprávněné a vychází z reálných problé-

38 Týž: U kolébky Sokola, s. 84.

39 Týž: Otevřrený list Národní radě československé v př́čině pozemkové opravy, s. 57.

40 Urban, Otto: Česká společnost 1848-1918. Praha 1982, s. 474.

41 ANM, fond LB, kart. č. 5, Červinka Bráfové, 30. 3. 1923. - Přílišná moc stran v novém státě byla v mnoha ohledech skutečně problematická, i když především v souvislosti s kvalitou a fungováním systému parlamentní demokracie, viz Broklová, Eva: Československá demokracie. Politický systém ČSR 1918-1938. Praha 1992, s. 74-75.

42 Červinka, V.: Od dětstvi do kmetství, s. 62.

43 ANM, fond LB, kart. č. 5, Červinka Bráfové, 1. 6. 1925.

44 1. května 1890 došlo v okolí Malče k dělnickým nepokojům, kdy se objevily i výhružky adresované přímo Riegrovi, což ale pravděpodobně souviselo i s tehdejšími spory kolem punktací. Podobné nepokoje se opakovaly také o rok později, viz Vojáček, M.: Na velkostatku vưdce národa, s. 192-193, 203. 
mů, současně se ale bál toho, že hledáním řešení mimo celonárodní rámec „pohřben bude na několik pokoleni smysl pro národnost, pro vlastenectvi zejména české - pakli bída přikryje vše ty city touhou po bochniku chleba. (...) Dosavadnimu směru Staro- i Mladočeskému odplavi se půda pod nohama - nebude ani možnost více - mluviti k lidu, účinkovati naň jménem a heslem vlasti!“. ${ }^{46}$ Důsledkem může být „sociálni prevrat“, při němž některá třída získá moc a skrze vládu bude diktovat svoji politiku bez ohledu na prospěch národního celku. ${ }^{47}$

K něčemu takovému v Červinkových očích po válce skutečně došlo. K moci se dostali lidé, jimž byla strana více než národ a kteří z ohledu na stranické zájmy udělali „ústavu a spoustu zákonů - které, ač skoro ještě ,teplé, již zavdávaji přićinu ke kritikám, které si nemüžeme dáti za rámeček, třeba bychom byli $i$ slepě zamilováni do naši samostatnosti a republiky...".48 Příkladem byla pozemková reforma. Červinka s její nutností v obecné rovině souhlasil, jako bývalý správce malečského velkostatku k ní však měl značné výhrady. Považoval ji za „tak stranicky zkomolenou a prováděnou, že z toho národu i státu musí povstat ohromná

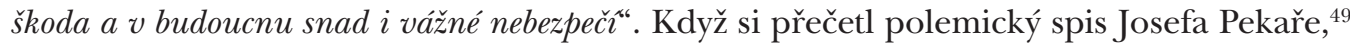
kterého si „velmi vážil“, rozhodl se, že svoje výhrady sepíše. Za peněžní dar, který dostal od Svatoboru za svoji spisovatelskou činnost, na vlastní náklady vydal Otevřený list, který adresoval Národní radě československé. ${ }^{50}$

Červinkův útlý spis na rozdíl od toho Pekařova nešel příliš do hloubky, trochu překvapivě v něm schází rozbor hospodářské stránky reformy a řešeny jsou především její morální aspekty. Kritizováno je paušální potrestání velkostatkářů vyplývající ze „stranické nenávisti“, nedostatečné odškodnění za zabranou půdu a nespravedlivé rozdělování půdy v ohledu „národnostním i společenském (sociálním)“. ${ }^{51}$ Příčinou těchto nedokonalostí bylo, že při plánování reformy byl více zohledněn volební úspěch zúčastněných stran než prospěch národa. ${ }^{52} \mathrm{~V}$ závěru brožury, která byla stejně tak kritikou pozemkové reformy jako obžalobou politického stranictví, Červinka varoval, že národu hrozí velká hmotná i mravní újma. Žádal proto, aby byla provedena zákonná oprava, která by při uskutečňování reformy podřídila požadavky stran potřebám národního celku, protože podle jeho přesvědčení „jest každý přislušnik československého národa předevšim Čechoslovákem, at' náleži kterékoli politické straně, a co takový jest mravně povinen obětovati své osobni a stranické zájmy zájmưm národního celku“. ${ }^{53}$ Červinka si uvědomoval, že jeho názory budou mít v soudobých poměrech minimální odezvu a jeho brožura, která dle všeho ani nešla do

46 Tamtéž. - Červinka se v tomtéž listu pokouší načrtnout řešení problému. Navrhl Bráfovi, který byl Riegrovým blízkým spolupracovníkem, aby staročeši převzali do svého programu některé požadavky těchto hnutí a udrželi je tak pro národ.

47 Tamtéž.

48 Červinka, Václav: Za padesát let bude zase všechno jinak. Samostatnost, 20. 5. 1926, s. 2-3, zde s. 2.

49 Pekař, Josef: Omyly a nebezpeči pozemkové reformy. Praha 1923.

50 ANM, fond LB, kart. č. 5, Červinka Bráfové, 7. 6. 1923. - Národní radu si Červinka zvolil právě pro nadstranickou pozici, kterou jí přisuzoval, viz Červinka, Václav: Otevřený list Národní radě československé v príčině pozemkové opravy. Praha 1923, s. 3. - Blíže k povaze a činnosti Národní rady viz Kodetová, Olga: Národni rada česká 1900-1950. Díl 1. Inventár. Praha 1970, s. 1-13.

51 Červinka, V.: Otevřený list Národni radě československé v přičině pozemkové opravy, s. 7.

52 Tamtéž, s. 6.

53 Tamtéž, s. 8. 
volného prodeje ${ }^{54}$ pravděpodobně upadne v zapomnění, ${ }^{55}$ přesto považoval za svoji morální povinnost se veřejně ozvat, ${ }^{56}$ zvláště když si byl jistý, že proti reformě by se postavil i jeho pratchán František Palacký, který byl pro něj, jak ještě uvidíme, vzorem ideálního vlastence. ${ }^{57}$

\section{Socialismus}

Více než konkrétní excesy zaviněné partikulárními zájmy jednotlivých stran Červinkovi vadilo celkové směřování nového státu. Zcela jistě by souhlasil s Masarykem, že vývoj po válce „ukazuje nalevo “ a že socialismus od převratu hraje v české politice významnou roli. ${ }^{58}$ Jenže zatímco Masaryk vnímal poválečné sociální reformy (stejně jako získání sociální demokracie pro budování státu) kladně, Červinka v tom spatřoval v duchu svých starších úvah nadvládu jedné zájmové skupiny nad národem, dokonce se veřejně vyjádřil, že zatímco dříve byla „diktatura monarchistického absolutismu pod škraboškou konstitučního parlamentarismu, “dnes je „částečná diktatura proletariátu (...) pod škraboškou svobody a demokracie“.59

Červinkovy dopisy a texty dokládají, že jejich autor byl díky svému původu, zážitkům z mládí a úzkým vazbám na vůdčí staročeské politiky Palackého a Riegra ideově zakotven v obrozeneckém pojetí vlastenectví a že touto optikou posuzoval i poválečné politické a společenské dění. Jeho soudy tak vycházely spíše z dojmů odpovídajících jeho již dávno utvořeným myšlenkovým schématům než z důkladného pozorování reality a přemýšlení o ní, ${ }^{60}$ což se projevilo i v případě jeho vztahu k socialismu. Pro Červinku byl socialismus neslučitelný s národní ideou, protože vycházel z př́slušnosti k určité třídě, nikoli národnímu celku. ${ }^{61} \mathrm{~V}$ tomto ohledu nespatřoval podstatný rozdíl mezi socialismem a komunismem ${ }^{62}$ a často tak hovořil o „nynějšim směru sociálně-komunistickém “63 který přitom spojoval s působením českých i zahraničních Židů. ${ }^{64}$

54 LA PNP, fond Václav Červinka, dopis Libuše Bráfové Václavu Červinkovi, 7. 7. 1923.

55 Že Červinkův spis „zapadne bez povšimnuti“ očekávala rovněž Libuše Bráfová, která svého švagra, který se v politických poměrech kvůli své izolaci př́liš neorientoval, upozornila na to, že předsedou Národní rady je agrárník Adolf Prokůpek, viz tamtéż.

56 ANM, fond LB, kart. č. 5, Červinka Bráfové, 10. 7. 1923.

57 Tamtéż, Červinka Bráfové, 21. 6. 1923.

58 Masaryk, Tomáš G.: Cesta demokracie. Díl 2. Praha 2007, s. 499.

59 Červinka, V.: Za padesát let bude zase v̌sechno jinak, s. 2.

60 Je př́značné, že Červinka málokdy reflektoval konkrétní politické události, které se ve 20. letech udály. Komentoval spíše obecné trendy a tendence. Je proto otázka, nakolik intenzivně politický život v první republice sledoval, i když z dopisů víme, že četl tisk, především Národni politiku.

61 „....kdysi byli jsme všichni nejdřive Češi a ve všech otázkách jen Češi, a nyni jsou nejpočetnějši držitelé moci nejdř́ve svazovci tř́dni. "Viz ANM, fond LB, kart. č. 5, Červinka Bráfové, 13. 11. 1919.

62 I v tom Červinka vycházel ze staršího pojetí socialismu a komunismu, viz Rieger, František Ladislav: Rozurh k přednáškám o politické oekonomice. Obzor národohospodářský, 1909, s. 257-266, zde s. 262-263.

63 ANM, fond LB, kart. č. 5, Červinka Bráfové, 17. 12. 1922.

64 Tamtéż, Červinka Bráfové, 13. 11. 1919. - Zde je třeba podotknout, že Červinkův antisemitismus, který je v jeho dopisech patrný, nebyl motivován rasově, ale spíše národnostně a hospodářsky, což bylo př́značné pro projevy českého antisemitismu v 19. století. 
Takový pohled samozřejmě nezohledňoval skutečný program sociálních demokratů ani složitý vývoj, kterým si strana od svých počátků až do poválečné doby prošla. Červinka nebral v úvahu ani vliv, který měli sociální demokraté a komunisté na meziválečnou politiku. Př́íznačné je, že explicitní kritika agrárníků, kteří představovali nejvlivnější stranu ve státě se v jeho písemnostech neobjevuje v podstatě vůbec. Byl totiž přesvědčen, že bez ohledu na reálné rozložení politických sil a rozdíly v programech jednotlivých stran není pochyb o tom, že „po válce kraluje socialismus “ ${ }^{65}$ který může za mnohé dobové nešvary. „Nenasytný socialismus“, který se musí „pořád krmit“, stojí např́íklad za stále novými daněmi, jimiž se má uspokojit „pořád vice žroutů, úřadník̊ a darmochlebů i jiných hloupých vydáni “. ${ }^{66} \mathrm{Na}$ vrub socialismu však podle Červinky padá především úpadek národního cítění. Mezi všemi stranami si tak zvláštní kritiku vysloužili právě sociální demokraté a komunisté, protože to byli pouze oni, kdo si troufal výslovně „odsuzovati vlastenectvi“ “67 Červinkovy obavy byly v tomto směru posíleny bolševickou revolucí z roku 1917, o níž psal jako o „zákeřném jedu“, který zničil Rusko a nyní je uměle přenášen do Československa, před čímž důrazně varoval ve své knize Od dětstvi do kmetstvi. ${ }^{68}$

Oproti tomu strany, které měly k národu „kladný“ postoj, dovedl Červinka ocenit. Nastala tak paradoxní situace, kdy se Riegerův zet’, staročech a před válkou zapřisáhlý odpůrce mladočechů, kteří zapříčinili pád „vůdce národa“ a „pokles“ české politické kultury, ${ }^{69}$ po převratu sblíżil s Československou národní demokracií, nástupkyní mladočeské strany: „Svého času do Staročechů a Riegra dosti bušili. Ale pak se to smírilo, a dnes je to snad jediná vlastenecká strana. "70 Tato proměna Červinkova postoje není příliš překvapivá, uvědomíme-li si, že už v 90 . letech vyslovil názor, že staročechy a mladočechy přece jen spojují určitá ideová a hodnotvá východiska, kterými se liší od nových politických proudů a zájmových stran. ${ }^{71}$ Jeho příklon k národní demokracii, která na tradiční mlado- i staročeskou politiku v mnoha ohledech navazovala, tak byl poměrně logický. Navíc jeden z mála politiků, o nichž se Červinka ve své korespondenci zmiňoval pochvalně, byl národní demokrat Alois Rašín. Chválil jeho opatření coby ministra financí pro uklidnění hospodářské situace po válce, ${ }^{72}$ oceňoval jeho ráznost i neoblomnost a litoval jeho smrti. ${ }^{73}$

Červinku v polovině 20. let zaujali rovněž fašisté. V roce 1926 napsal: „Já s fašisty sympatisuji, ale již se $k$ nim nedám. Jiného východiště než $k$ př́ínému nacionalismu z té stranické internacionálni kaše neni. "74 Jeho postoj k fašismu byl ovšem ambivalentní a podobný

65 Tamtéž, Červinka Bráfové, 28. 4. 1921.

66 Tamtéž, Červinka Bráfové, 28. 1. 1928. - Červinka narážel na Englišovu reformu daňového systému z roku 1927. O jejích skutečných motivech viz Vencovský, František: Karel Engliš. Brno 1993, s. 33-34.

67 Červinka, V.: Za padesát let bude zase všechno jinak, s. 2.

68 Týž: Od dětstvi do kmetství, s. 60-62.

69 Srov. ANM, fond LB, kart. č. 5, Červinka Bráfové, 23. 6. 1910; 25. 11. 1912.

70 Tamtéž, Červinka Bráfové, 27. 4. 1926.

71 Tamtêž, fond Albín Bráf, kart. č. 5, Červinka Bráfovi, 23. 3. 1891.

72 Tamtéž, fond LB, kart. č. 5, Červinka Bráfové, 8. 3. 1919.

73 Tamtéż, Červinka Bráfové, 10. 7. 1923.

74 Tamtéž, Červinka Bráfové, 20. 6. 1926. 
tomu, který zastávali např. Karel Kramář a Viktor Dyk. ${ }^{75}$ Červinkovi, který se s fašismem seznámil skrze četbu Národni republiky, musely být některé ideové teze českého fašismu sympatické, například již zmíněný vyhraněný nacionalismus, ale také kritika stranictví, socialismu a současných poměrů. Je ale otázkou, nakolik Červinka českým fašistům rozuměl, protože přiznával, že nezná „ani jich program a stanovy “, ${ }^{76}$ což však mohlo být zapříčiněno i tím, že český fašismus samotný měl se svým programem a vymezením problémy. ${ }^{77}$ Červinka od něj čekal především posílení národního cítění ve společnosti, uznával ale, že fašismus „ve suých písemných projevech též někdy chybuje, dilem proto, že přestřeluje, dilem proto, že svou věc vede a háji poněkud ploše a mělce, patrně se mu nedostává dosti vzdělaných sil. "78 Červinkův zájem o fašisty (alespoň v jeho korespondenci) skončil zklamáním. Když nevyšly pokusy o sjednocení hnutí a od Národní obce fašistické se odpojila skupina kolem Roberta Macha, ${ }^{79}$ komentoval to ironickými slovy: „Okázalo se, že máme stran ještě málo: rozdvojili se také - obě strany pravdu maji a o ni se hádají. "80

\section{Realismus a humanismus}

V novém státě podle Červinky panovala vedle socialismu ještě další mocná síla, která se snažila národní cítění oslabit. Označoval ji jako „humanismus“ a „realismus“, z čehož je zřejmé, kam jeho kritika míŕila. Ani v tomto případě nešlo o nový jev, Červinka se negativně díval už na předválečný realismus reprezentovaný Masarykem a Kaizlem, ${ }^{81} \mathrm{v}$ čemž mohl hrát roli i komplikovaný vztah Masaryka a Riegra. ${ }^{82} \mathrm{~K}$ osobě prezidenta tak měl Červinka rezervovaný postoj, který ale ve svých publikovaných textech otevřeně nevyjadřoval, naopak se jeho názory neváhal zaštítit při své kritice pozemkové reformy. ${ }^{83}$ Méně uctivý byl k hlavě státu v soukromé korespondenci, kde psal o „Masařykovi“ nebo „sv. Masarykovi “. ${ }^{84}$ Především mu ale vadilo, že v osobě prezidenta a tzv. Hradu získala tato ideová a politická linie mocnou záštitu a stala se v podstatě oficiální ideologií československého státu zaměřenou proti staré podobě vlastenectví: „Riegrovské kdysi vlastenectvi je

75 Tomeš, Josef: Viktor Dyk a T. G. Masaryk. Dvojí reflexe češství. Praha 2014, s. 75.

76 ANM, fond LB, kart. č. 5, Červinka Bráfové, 17. 7. 1926.

77 Srov. Vykoupil, Libor: Český fašismus na Moravě. Brno 2012, s. 37-51, 159.

78 ANM, fond LB, kart. č. 5, Červinka Bráfové, 8. 12. 1926.

79 Vykoupil, L.: Český fašismus na Moravě, s. 99-103.

80 ANM, fond LB, kart. č. 5, Červinka Bráfové, 4. 5. 1927.

81 Tamtéž, Červinka Bráfové, 25. 11. 1912.

82 Viz Kokešová, Helena - Bílek, Jan: Vztahy T. G. Masaryka s představiteli a stoupenci Národni strany v Čechách v zrcadle jejich vzájemné korespondence. In: Korespondence T. G. Masaryk - staročeši. Praha 2009, s. 5-39. - Autoři bohužel nesledují vztah Masaryka k Riegrovi v období první republiky, ale z prezidentových soukromých i veřejných vyjádření se zdá, že jeho pohled na osobnost a odkaz bývalého „vůdce národa“ byl i nadále ambivalentní.

83 Červinka, V.: Otevřený list Národni radě československé v přičině pozemkové opravy, s. 5.

84 ANM, fond LB, kart. č. 5, Červinka Bráfové, 6. 8. 1924; 28. 4. 1921. 
na indexu, zatlačeno realismem, socialismem, humanismem, prospěchářstvím. "85

Když byl Červinka při 50. výročí Palackého smrti roku 1926 požádán redakcí Samostatnosti, aby napsal vzpomínku na „Otce národa“, vznikl text, který byl přímou polemikou s tímto „realisticko-humanistickým“ světonázorem a současně nejucelenější Červinkovou úvahu na téma „jindy a nyni“. ${ }^{86}$ Vyjádřil se v ní k hodnotám, na nichž Československo dle jeho soudu spočívalo, podrobil je zevrubné kritice a také nabídl vlastní představu, k jakým zásadám by se měla česká společnost hlásit. Ačkoli ve svém článku záměrně nikoho nejmenoval, uvědomoval si, že jeho obsah vyzní jako kritika Masaryka, a obával se, zda kvưli tomu text nakonec vyjde. Záleželo podle něj na tom, jestli je vydavatelstvo „smýšleni národnè-demokratické strany Kramářovy“, nebo tam rozhoduje „smýšlení realisticko-sociálně-humanistické“. Mátlo jej v tomto ohledu „podezřelé “jméno člena redakce Antonína Hajna, bratra Aloise Hajna, Masarykova přítele a někdejšího spolupracovníka. ${ }^{87}$ Antonín byl ovšem národní demokrat a polemicky laděný článek mu tak pravděpodobně nevadil. ${ }^{88}$

V úvodu svého pojednání Červinka zavzpomínal na Palackého smrt a následný velkolepý pohřeb, načež si položil otázku: „Jak pưsobila by asi na mysl Palackého naše česká dnešni přitomnost? "Pro Palackého bylo vlastenectví nesmírně důležité, což osvědčil celým svým životem a dílem. Dnes ale „místo hesla ,vlastenectvi rozléhá se u nás heslo ,internacionalismus', t. j. ,mezinárodnictvi‘, kryjíci se bohužel obyčejně pláštikem, humanismu', velmi pohodlným... “. Toto mezinárodní cítění „pokládá se nyní za lidštějšš, ,humánnějši a tudiž pokrokovější, kdežto mnozi se snaži shližeti na vlastenecké národni smýšleni a cítěni jako na cosi surovějšího, prežilého a zaostalého a na příčinu válek ". 89

Červinka takovéto vnímání národního cítění striktně odmítal a kritizoval zaměňování vlastenectví a šovinismu. ${ }^{90}$ Skutečné vlastenectví „jest láska $k$ suým rodným a $k$ vlastni domovině, jest cit mravný, a nevyžaduje nenávisti k jiným národům, kteři nám neubližuji“. Naopak internacionalismus a humanismus mohou být velmi nebezpečné pro samostatnost národa, dokud „naši sousedé Němci ${ }^{91}$ a jednotliví jini národové stoji na stanovisku výboje, msty,

85 Tamtéž, Červinka Bráfové, 15. 10. 1925.

86 Červinka, V.: Za padesát let bude zase v̌̌echno jinak, s. 2.

87 ANM, fond LB, kart. č. 5, Červinka Bráfové, 5. 5. 1926.

88 V dopise Červinkovi Hajn vyjádřil spokojenost se zaslaným textem o Palackém, pokud se samozřejmě nejednalo o pouhý projev zdvořilosti vůči autorovi, viz tamtéž, fond Marie Červinková-Riegrová, kart. č. 39, inv. č. 600, Hajn Červinkovi, 10. 5. 1926.

89 Červinka, V.: Za padesát let bude zase všechno jinak, s. 2.

90 Spory o rozdílech mezi vlastenectvím, nacionalismem a šovinismem byly v meziválečném Československu velmi živé, zvláště mezi T. G. Masarykem a jeho kritiky z řad pravice, např. V. Dykem, viz Tomeš, Josef: Nacionalismus a demokracie. Úskalí české nacionální strany v meziválečném Československu. In: Agrárníci, národní demokraté a lidovci ve druhém poločase první Československé republiky. Edd. E. Broklová - M. Pehr - J. Tomeš. Praha 2008, s. 130-213, zde s. 136-145. - Př́ičinou sporů byla především neujasněnost jednotlivých pojmů. Také Červinka nikdy nepodal žádnou definici vlastenectví, protože tento pojem používal jako něco zcela samozřejmého, co vysvětlení nepotřebuje. Pouze nepřímo se tak můžeme z jeho různých vyjádření dozvědět, co pro něj vlastenectví znamenalo a čím se mělo vyznačovat, například láskou k národu, obětavostí, nezištností, pracovitostí, svorností s národním celkem, který má stát nad dílčími zájmy.

91 Zatímco ve veřejných textech Červinka psal o Němcích (zahraničních i domácích) jako o potenciální hrozbě pro stát, v jeho dopisech se toto téma neobjevuje, na rozdíl od stálé kritiky vlastního národa. Zdá 
zotročování a odnárodňování jiných. (...) Tudiž tam, kde neni vlastniho zabezpečeni neodvislosti, hraniči internacionalismus na vlastizradu, byt' křičel, že jde za praporem, humanity “. Internacionalismus může být podle Červinky pěstován pouze mezi sobě rovnými a navzájem zabezpečenými národy, jinak představuje záruku svobody jedině silný vlastenecký cit a ochota se pro národ obětovat, jak tomu bylo za války. ${ }^{92}$

Červinka ale nezamítal styky mezi národy a humanismus jako takové, pouze jejich podobu prosazovanou po válce. Jako pozitivní příklad a vzor hodný následování stavěl právě Františka Palackého. V jeho případě by bylo možné vystopovat mnoho rysů internacionalismu od jeho znalosti jazyků, přes kontakty, zcestovalost až k módě, kterou nosil. Palacký byl současně skutečným humanistou, jakým ostatně musí být dle Červinkova soudu každý pravý učenec. Přitom všem ale „přece zůstal do posledniho dechu nejryzejším vlastencem, Čechem “. ${ }^{93} \mathrm{~V}$ tom viděl Červinka rozdíl oproti současným „humanistům“. Zde je třeba poznamenat, že podobně jako v případě socialismu byla značně zkreslená a zjednodušená i Červinkova představa o Masarykově filozofii, kterou posuzoval svojí obrozenecko-staročeskou optikou. Na druhou stranu také Masaryk mnohdy vnímal své názorové odpůrce poněkud jednostranně ${ }^{94}$ a spory mezi prezidentem a jeho kritiky je proto nutné vždy posuzovat komplexně jako střetávání různých světonázorových proudů, do něhož z obou stran zasahovaly mnohé osobní animozity založené na dřívějších zkušenostech.

Masarykův směr byl pro národ podle Červinky „nebezpečný“ ještě v jednom, pro něj velmi citlivě vnímaném, ohledu. Nejenže podle něj potlačoval tradiční vlastenectví v každodenním životě české společnosti, pokoušel se je vymýtit také v symbolické rovině tím, že vzpomínku na ně vymaže z paměti národa. Červinka proto v závěru svého článku kritizoval snahy „trochu premalovat, retušovat názory dnešního lidu o některých podáních z minulosti, po př́padě o některých zásluhách našich pracơníku… “. Jméno nejedné významné osoby „nám kdysi mnoho představujicí - ač neni-li vưbec dáno ,na index“ - smi se někdy priplésti jen tak mimochodem v průvodu nově objevených velikánů “. ${ }^{95}$ Červinka například s nelibostí sledoval, že v prvorepublikovém tisku je opomíjen Rieger, a místo něho jsou vyzdvihováni lidé jako Jan Skrejšovský a Bedřich Smetana, jejichž skutečným či domnělým odpůrcem Rieger byl, „aby se zase pokaňkal kus Riegrovy památky a popularity “.96 Psát v této atmosféře cokoli politického o Riegrovi je „věc choulostivá a nevděčná“, protože některé věci se veřejně nesmějí, nebo alespoň nemají řrikat. ${ }^{97}$ Červinka se domníval, že právě kvưli tomu vydavatel vypustil z jeho vzpomínek některé pasáže, které kriticky pojednávaly o současných poměrech. ${ }^{98}$

se tak, že Červinka spatřoval hlavní nebezpečí pro svobodu nikoli ve vnějším nebezpečí, ale ve vnitřní semknutosti národa a pevnosti vlasteneckého cítění, což vyplývá i z obsahu jeho článku v Samostatnosti.

Červinka, V.: Za padesát let bude zase v̌sechno jinak, s. 2.

93 Tamtéž.

94 Tomeš, J.: Nacionalismus a demokracie, s. 136. - Kocourek, Katya: Čechoslovakista Rudolf Medek. Politický životopis. Praha 2011, s. 175-176.

95 Kocourek, K.: Čechoslovakista Rudolf Medek. s. 175-176.

96 ANM, fond LB, kart. č. 5, Červinka Bráfové, 14. 2. 1926.

97 Tamtéz̆, Červinka Bráfové, 2. 3. 1925.

98 Tamtéż, Červinka Bráfové, 17. 12. 1922; 14. 5. 1923. - Rukopis Červinkovy knihy se v jeho pozůstalosti nenachází, takže nelze zjistit nakolik se vydaná kniha od původního textu odlišuje. 
V korespondenci proto vyjadřoval radost z každé pozitivní zmínky, která se o Riegrovi a jeho „směru“ objevila ve veřejném prostoru. S nadšením přivítal také zprávu Libuše Bráfové, že stále existují obránci pravosti rukopisů Královédvorského a Zelenohorského. ${ }^{99}$ Červinka v jejich pravost věřil ${ }^{100}$ a měl k nim i silný osobní vztah, protože milostné písně z rukopisu Královédvorského „viríly v hlavách“ mladých lidí v 60. letech. ${ }^{101}$ Jeho zájem o rukopisy nepochybně vycházel také ze skutečnosti, že jejich obhajoba, o které sám uvažoval a nakonec o nich učinil alespoň letmou zmínku ve svém článku v Samostatnosti ${ }^{102} \mathrm{v}$ podstatě byla nepřímým vymezením se vůči Masarykovi, jeho pojetí českého národa a jeho předválečné veřejné činnosti. To se potvrdilo ke konci 20. let, když za pravost rukopisů začali bojovat i další Masarykovi názoroví odpůrci jako František Mareš. ${ }^{103}$ Zápas s realismem pro Červinku tedy nebyl pouze otázkou odlišných hodnot a rozdílného pojetí vlastenectví, ale také sporem o interpretaci nedávné minulosti, na jejímž odkazu mu záleželo především.

Červinkovy soudy založené na obrozeneckých ideálech by v tehdejší době mohly působit jako anachronická kuriozita, ve skutečnosti ale ve velké míře souzněly s postoji meziválečné protihradní opozice, zvláště národní demokracie. Červinkova kritika Masaryka, určitého kultu, který se kolem něj začal ve veřejném prostoru utvářet, humanismu a internacionalismu oslabujících národní cítění, „přebujelého“ stranictví, socialismu a komunismu měla velmi blízko k názorům Viktora Dyka, který byl jedním z nejvýraznějších hlasů pravicové opozice. ${ }^{104}$ Styčné body bychom mohli nalézt také v Dykově a Červinkově idealismu, preferencích národního státu před státem národnostním a v jejich pojetí nacionalismu, který měl být položen na silném etickém základě doprovázeném kritickým pohledem na chyby vlastního národa. ${ }^{105}$

I když se Červinkův případ vyznačuje některými specifiky, jako je nostalgický tón jeho textů nebo důraz, který jako pamětník klade na minulost a její porovnávání s přítomností, byla by chyba nevnímat jej jako součást podstatně širšího fenoménu souvisejícího s celkovou modernizací (nejen) české společnosti na přelomu 19. a 20. století. Někteří,

99 Tamtéž, fond Marie Červinková-Riegrová, kart. č. 39, Bráfová Červinkovi, 29. 3. 1925. - Zmíněni byli v listu např. Josef Bareš, Josef Schneider a v tu dobu již zesnulý Václav Řezníček. Stejně jako Červinka také Bareš soudil, že v soudobých poměrech je obtížné o podobných věcech veřejně psát, ale vyjádřil naději, že „až tu nebude president, nastane ještě v té věci obrat (....)“.

100 ANM, fond LB, kart. č. 5, Červinka Bráfové, 7. 4. 1925.

101 Červinka, V.: Od dětstvi do kmetství, s. 47.

102 Týž: Za padesát let bude zase všechno jinak, s. 2. - ANM, fond LB, kart. č. 5, Červinka Bráfové, 5. 5.1926.

103 Pavličíková, Helena: František Mareš. Od fyziologie k filosofii. Praha 2017, s. 236-250, zvl. 243.

104 K Dykovým názorům viz Tomeš, J.: Viktor Dyk a T. G. Masaryk. - Velký rozdíl oproti národnědemokratické opozici spočíval v tom, že Červinka se př́liš nezabýval zahraničněpolitickou otázkou a také u něj nenalezneme kritiku Edvarda Beneše, která přitom byla pro Kramáře a Dyka zásadní. Rovněž se lišilo hodnocení a interpretace Riegrova odkazu. Např́iklad Viktor Dyk si Riegra v mnoha ohledech vážil, současně ale hodnotil značně kriticky některé jeho povahové rysy a konkrétní politické kroky, viz Dyk, Viktor: Riegriov západ. In: O národní stát. Díl 5. 1928. Ed. V. Dyk. Praha 1937, s. 62-68.

105 Červinka, V.: Otevřený list Národni radě československé v přićině pozemkové opravy, s. 3. - Tomeš, J.: Viktor Dyk a T. G. Masaryk, s. 33. - Týž: Nacionalismus a demokracie, s. 144-145. - Přes toto myšlenkové souznění se mi v Červinkově korespondenci ani v jeho literárním díle nepodařilo najít jakoukoli zmínku o Dykovi a jeho tvorbě. 
např́íklad Masarykovi realisté nebo sociální demokraté, tyto změny vítali jako „pokrok“ a příležitost pro uplatnění svého vlastního programu a politických ambicí. Přirozeně ale existovali tací (především ti, kteří doposud mocensky dominovali), kteří měli z různých důvodů k novým trendům a jevům výhrady a oporu proti nim stejně jako obranu svých mocenských pozic hledali v osvědčených hodnotách, zvláště v národu a vlastenectví. ${ }^{106}$ Při zápasu těchto dvou ideových proudů, který v poněkud pozměněné podobě a za odlišného rozložení sil pokračoval i za první republiky, se tak mohl v jednom názorovém táboře setkat Červinka formovaný 60 . lety 19. století s bývalým pokrokářem Dykem a mladočechem Kramářem, ale i mnoha dalšími.

Potvrzuje se tak, že meziválečná protihradní opozice byla velice pestrým útvarem, a ačkoli je otázka, zda lze Červinku považovat za její přímou součást, protože se politického a veřejného dění účastnil pouze okrajově a sám nepatřil k žádné straně, můžeme díky němu lépe pochopit některé názory, motivy a argumenty, které velká část kritiků tzv. Hradu, případně prvorepublikových politických a společenských poměrů sdílela. Rovněž tak mohou být sledovány ideové střety mezi oběma tábory, ale i vztah meziválečné společnosti a jejích politických a kulturních elit k historické paměti. Ukazuje se totiž, že i v Československu probíhal určitý „boj o minulost“, ačkoli se svojí intenzitou a významem nemohl ani zdaleka rovnat tomu, který známe z Výmarské republiky. ${ }^{107}$

Červinkův význam pro badatele pak spočívá v tom, že nám umožňuje doplnit analýzu tisku a názorů vưdčích postav tehdejšího veřejného života pohledem „zdola“. Šlo o osobu, která nebyla aktérem, ale spíše vnějším pozorovatelem, což je perspektiva, která se kvůli nedostatku pramenů většinou velmi obtížně sleduje. U Červinky je navíc ta výhoda, že jeho názory a aktivity dokážeme díky bohatému pramennému materiálu zasadit do širšího kontextu, můžeme sledovat, co jej formovalo, kdo jej ovlivnil a jak se jeho názory vyvíjely. Nabízí se nám tu poněkud jiný, ale o to zajímavější úhel pohledu, než na jaký jsme při studiu tématu meziválečné protihradní opozice zvyklí.

\section{Závěr}

Zhodnotit poválečné působení Václava Červinky je poměrně komplikovaný úkol. Červinka byl člověk 19. století, a to spíše jeho první poloviny ovlivněné obrozeneckým vnímáním národa a jeho povahy. Tomuto pohledu na svět nejlépe odpovídal Červinkův prožitek počátku 60. let 19. století. Tehdejší proklamovaná národní jednota, entuziasmus a obětavost, o kterých snad lze v souvislosti s pádem Bachova absolutismu hovořit, však v podmínkách svobodného politického a ideového střetávání a stále komplikovanějších společenských vazeb, které s sebou přinášela moderní doba, nemohly vydržet dlouho. To se ostatně potvrdilo už během 60 . let. Červinkovi se však tato s přibývajícím věkem

106 Rozdílnými reakcemi na přerod české společnosti na přelomu 19. a 20. století jsem se okrajově zabýval ve své diplomové práci, viz Máša, Pavel: „Kus české historie je ukončen... “Pohřební a vzpomínkové rituály při úmrtí zakladatelů české politiky. Nepublikovaná diplomová práce. Historický ústav FF MU. Brno 2015, s. 25-29.

107 Gerwarth, Robert: Der Bismarck Mythos. Die Deutschen und der Eisene Kanzler. Berlin 2007, s. 13. 
stále silněji idealizovaná minulost, kterou v jeho očích ztělesňovali staročeští předáci Palacký a Rieger, stala měřítkem, jímž hodnotil soudobé poměry, které při tomto srovnání pochopitelně nemohly obstát. Z tohoto hlediska byl pro Červinku vývoj v osvobozené vlasti po roce 1918 zklamáním, protože komplikovaná realita poválečného Československa stále méně odpovídala poměrně jasným a jednoduchým myšlenkovým schématům a hodnotovému systému, které si vytvořil během svého dospívání a zralých let.

Červinka se s novými poměry, které neodpovídaly jeho představám národního života a ideálních vlasteneckých hodnot, nesmírill. Kritizoval je, varoval před jejich možnými důsledky a současně hájil starý, dávno ztracený svět, ve kterém hledal útěchu a řešení soudobých problémů. Proto také vítal domnělé ozvěny tohoto zmizelého světa, jakými pro něj byly například Sokol, fašistický nacionalismus či obnovená obrana rukopisů. V duchu svých ideálů přitom Červinka neváhal obětovat vlastní čas a finanční prostředky, aby skrze svoje literární dílo prospěl národu, na kterém mu záleželo, i když pro něj měl stále méně pochopení. Činil tak s vědomím, že jeho boj s přítomností je marný, ale nezbytný a oprávněný, protože pravda „je na jeho straně“ a národ bude po zklamáních, která jej velmi pravděpodobně čekají, „staré doby jednou oslavovat a památky na ně špendličkem z rumů a sutin vyhrabávat a sbirat “. ${ }^{108}$ Červinka tak mohl přinejmenším podat svědectví o zaniklém světě, aby se na něj v tom novém zatím úplně nezapomnělo. ${ }^{109}$

\section{The end of the old world in the view of Václav Červinka}

Václav Červinka, son-in-low of František Ladislav Rieger, director of his estate Maleč and husband of his daughter Marie, retired after Rieger's death in 1903. He lived in solitude, wherefrom he observed public affairs, especially the First World War and the foundation of the Czechoslovakia. After the original enthusiasm for the independence of the new state, he was disappointed with development, values and character of the post-war Czech society. Červinka was born in the middle of the 19th century, he was a "son" of the Czech national revival and its conception and understanding of patriotism. He was also under the strong influence of oldczechs leaders Palacký and Rieger. For these reasons ideas of the national unity and a strong national feeling were very important for him. In his view the First Republic left the old proven values of the national revival. He was convinced, that main dangers for the nation and patriotism among the people were: political parties, which prefer particular interests of some part of society instead of national interests, socialism and communism, because for them working class is more important than the nation, and political realism represented by new president of Czechoslovakia Tomáš Garrigue Masaryk and his followers. According to Červinka realism is an enemy of patriotism because of Masaryk's false conception of "cosmopolitism" and "humanism". Červinka thought, that new political elites

108 ANM, fond LB, kart. č. 5, Červinka Bráfové, 17. 12. 1922.

109 Sem by bylo možné zařadit také Červinkovu péči o rodinný archiv, který chtěl především kvưli Riegrovým písemnostem zachovat pro budoucí generace, nebo jeho spoluúčast při snaze Libuše Bráfové o vznik Riegrovy velké biografie, která by kodifikovala „náležitý“ výklad role „vůdce národa“ v moderních českých dějinách. Činnost Červinky a Bráfové coby strážců Riegrova odkazu v meziválečné době je poměrně rozsáhlé a komplikované téma, které postupně zpracovávám, a proto jsem jej v této studii záměrně vynechal. 
wanted to eliminate old form of patriotism embodied by Rieger and Palacký and even to erase it from collective memory of the Czech people. He criticized these tendencies in his personals letters and he also wrote several literary works, which criticized post-war life and tried to remember and preserve "old good values" of Červinka's time of youth in the memory of the recent Czech society.

\section{Prameny}

\section{Archivní prameny:}

Archiv Národního muzea v Praze:

- fond Albín Bráf

- fond Bohuš Rieger st.

- fond Libuše Bráfová

- fond Marie Červinková-Riegrová

Literární archiv Památníku národního písemnictví v Praze:

- fond Václav Červinka

- fond Václav Vlček

\section{Vydané prameny:}

Červinka, Václav: Z jarního rašení národního života v letech 1855-1865. Osvěta, 1912, s. 272-278, 370-375, 437-444, 514-522, 665-672, 748-751.

Červinka, Václav: (Renatus, Q. F.): Za Otakarem Červinkou. Národní politika, 11. 6. 1915, s. 2-3.

Červinka, Václav: U kolébky Sokola. Vzpomínky účastníkovy. Praha 1920.

Červinka, Václav: Od dětství do kmetství. Některé vzpomínky, zážitky a úvahy. Praha 1923.

Červinka, Václav: Otevřený list Národní radě československé v př́ícině pozemkové opravy. Praha 1923.

Červinka, Václav: Za padesát let bude zase všechno jinak, Samostatnost, 20. 5. 1926, s. 2-3.

Dyk, Viktor: Riegrův západ. In: O národní stát. Díl 5. 1928. Ed. V. Dyk. Praha 1937, s. 62-68.

Masaryk, Tomáš Garrigue: Cesta demokracie. Díl 2. Praha 2007.

Pekař, Josef: Omyly a nebezpečí pozemkové reformy. Praha 1923.

Rieger, František Ladislav: Rozvrh k přednáškám o politické oekonomice. Obzor národohospodářský, 1909, s. 257-266.

Kramář, Karel: ̌̌eči a projevy předsedy prvé vlády československé. Praha 1936.

Zweig, Stefan: Svět včerejška. Praha 1994.

Vojáček, Milan: Na velkostatku vůdce národa. Edice Pamětní knihy Malče. Praha 2014.

\section{Literatura}

Broklová, Eva: Československá demokracie. Politický systém ČSR 1918-1938. Praha 1992.

Gerwarth, Robert: Der Bismarck Mythos. Die Deutschen und der Eisene Kanzler. Berlin 2007.

Kárník, Zdeněk: České země v éře první republiky (1918-1938). Díl 1. Vznik, budování a zlatá léta republiky (1918-1929). Praha 2003. 
Kocourek, Katya: Čechoslovakista Rudolf Medek. Politický životopis. Praha 2011.

Kodetová, Olga: Národní rada česká 1900-1950. Díl 1. Inventář. Praha 1970.

Kokešová, Helena - Bílek, Jan: Vztahy T. G. Masaryka s představiteli a stoupenci Národní strany v Čechách v zrcadle jejich vzájemné korespondence. In: Korespondence T. G. Masaryk - staročeši. Praha 2009.

Kováč, Dušan: 1918. Začiatok, alebo koniec? Dva transformačné modely v strednej Európe. In: 1918. Model komplexního transformačního procesu? Edd. L. Kostrbová - J. Malínská a kol. Praha 2010, s. 11-20.

Pavličíková, Helena: František Mareš. Od fyziologie k filosofii. Praha 2017.

Pók, Attila: Ungarische Interpretationen der Gründung der Tschechoslowakei. In: 1918. Model komplexního transformačního procesu? Edd. L. Kostrabová - J. Malínská a kol. Praha 2010, s. 39-49.

Putna, Martin C.: Česká katolická literatura 1918-1945. Praha 2010.

Magris, Claudio: Habsburský mýtus v moderní rakouské literatuře. Brno - Praha 2001.

Máša, Pavel: „Kus české historie je ukončen...“ Pohřební a vzpomínkové rituály při úmrtí zakladatelů české politiky. Diplomová práce. Historický ústav FF MU. Brno 2015.

Neradová, Zlatuše: Václav Červinka. Ze života rodiny českého vzdělance ve druhé polovině 19. století. Diplomová práce. PF JU. České Budějovice 1994.

Tomeš, Josef: Nacionalismus a demokracie. Úskalí české nacionální strany v meziválečném Československu. In: Agrárníci, národní demokraté a lidovci ve druhém poločase první Československé republiky. Edd. E. Broklová - M. Pehr - J. Tomeš. Praha 2008, s. 130-213.

Tomeš, Josef: Viktor Dyk a T. G. Masaryk. Dvojí reflexe češství. Praha 2014.

Urban, Otto: Česká společnost 1848-1918. Praha 1982.

Vencovský, František: Karel Engliš. Brno 1993.

Vojáček, Milan: Odkaz budoucím generacím. Literární obraz vlastní rodiny vytvořený Marií Červinkovou-Riegrovou a jejím chotěm Václavem Červinkou. In: Žena umělkyně na přelomu 19. a 20. století. Sborník příspěvků z mezinárodní konference ve Středočeském muzeu v Roztokách u Prahy ve dnech 11. a 12. ř́ijna 2005. Roztoky u Prahy 2005, s. 209-216.

Vykoupil, Libor: Český fašismus na Moravě. Brno 2012. 
